\title{
Performance Enhancement Strategy through Business Environment, Product Innovation and Competitive Advantages
}

\author{
Maat Pono ${ }^{1}$, Andi Reni ${ }^{2}$, Isnawati Osman ${ }^{3}$, Meutia A. S. ${ }^{4}$ and Rahmawati Harisa ${ }^{5}$ \\ ${ }^{1}$ Hasanuddin University, Indonesia \\ ${ }^{2}$ Hasanuddin University, Indonesia \\ ${ }^{3}$ Hasanuddin University, Indonesia \\ ${ }^{4}$ Hasanuddin University, Indonesia \\ ${ }^{5}$ University of West Sulawesi, Indonesia
}

\begin{abstract}
This research tries to examine the influence of business environment, product innovation and competitive advantage on SME performance. The type of research is survey. The population in this study is the overall SMEs in South Sulawesi. The sampling technique is simple random sampling with the number of respondents is 300 respondents Statistical technique used is Path Analysis The result of research indicates that: (1) there is positive influence of business environment to product innovation, (2) there is positive influence of business environment to competitive advantage, (3) there is positive effect of product innovation on SME performance, (4) there is a positive influence of competitive advantage on SME performance. The practical implication is that it should continue to improve its business orientation by making clearer vision and business goals by developing longer-term and clearer business plans.

Keywords: business environment, product innovation, competitive advantage, performance
\end{abstract}

\section{Introduction}

In an increasingly competitive environment and consumers are increasingly critical in choosing products, companies are required to be more innovative in producing a product. Many competing strategies to be market winners include product innovation strategies. Product development or product innovation is very important in today's market competition. All efforts, power owned by the company, directed to produce value in accordance with the expected, because a better result means to have value add compared with competitors. But to produce more value or superior value obtained through various innovative developments. Thus the goal to be achieved in developing the strategy is to produce superior value or service much better than that of competitors (Ferdinand, 2000).

With the right product innovation for the market, the performance of a company will increase; it can be seen from the increase of existing sales, the increasing market share and the company's increasing profit. Thus a company can be said to succeed in a competitive strategy that leads to a competitive victory in the face of markets and competitors in product innovation. Muafi (2008) states that in a changing business environment product innovation is needed to support the competitiveness and performance of the company. Innovation strategy is the main driver of small and medium enterprise (SME) performance by applying strategic and structured innovation culture. Applied innovation methods can enable SMEs to compete and survive in a competitive global environment.

Small and Medium Enterprises (SMEs) as one component in the national industry, has an important role in the national economy, employment, equitable distribution of development outcomes and for poverty. Therefore, in order to support its development and empowerment, the government already has strategic policy pillars that have been implemented through annual programs and activities. Based on data from the Central Bureau of Statistics and Ministry of Cooperatives and SMEs, the number of SMEs recorded 42.39 million units or $99.9 \%$ of all business units. Second, its great potential in absorbing labor. Each investment unit can create more employment opportunities when compared to the same investment in large enterprises. 
There are three conditions for the development of SMEs business, namely: (1) conditions related to entrepreneurs, namely skills and attitudes, (2) conditions related to the company, namely the structure of capital and corporate culture, and (3) conditions related to the environment, namely the choice of strategy. Craicg and King (1988) argue that the characteristics of the owner of the firm's managers are the decisive foundation of the firm's performance; the company's characteristics affect the business or market environment, the company's goals, and the management skills which in turn will affect the growth performance of the company.

The classical business of SMEs in South Sulawesi is the decline of its performance. This is due to limited capital, marketing difficulties, production aspects, resource constraints and the use of traditional technology. Therefore, for the development and improvement of the business, an appropriate strategy is needed, namely a strategy to produce innovative products that can compete in a tight competition environment to improve SME's performance in South Sulawesi. This study aims to examine the influence of the business environment on product innovation and competitive advantage. Test the effect of product innovation on SME performance. Test the influence of competitive advantage on SME performance.

Business Environment. The competitive situation in the industry depends on the five forces. According Pearce and Robinson (2007), there are five forces that shape competition in an industry that is inter-industrial competition, newcomer threats, substitution threats, bargaining power and bargaining power of suppliers. This competitive environment situation can be used to formulate the right strategy. Competition environments can encourage creativity, as knowledge of the competitive environment highlights opportunities that can be highlighted and weaknesses to be taken into account (Menon et al, 1999). The addition of the environment to resources that support the company's strategy, emphasizes the importance of the company's internal ability to operate and how far its economic social environment is affected.

Product Innovation. By innovating a company can differentiate itself and its products from its competitors, so innovation can provide a way for companies to create competitive advantage. In addition, innovation culture also encourages exploration and experimentation to develop new business in existing business and ongoing business renewal (Slater \& Narver, 1995).

Competitive Advantages. Competitive advantage has two different but related meanings. The first sense emphasizes superiority or superiority in terms of resources and expertise of the company. Companies that have competencies in marketing, manufacturing, and innovation can make it as a source to achieve competitive advantage. Through these three areas of competence, the company can develop strategies so as to produce products sold in the market. While the second understanding emphasizes the superiority in achievement of performance over the years. This understanding is related to the company's position compared to what its competitors are. Companies that continue to pay attention to the progress of their performance and strive to improve the performance have the opportunity to achieve a good competition position then the company actually has strong capital to continue to compete with other companies (Droge and Vickrey, 1994).

Performance. Company performance is a reflection, whether the company has succeeded or not. Performance is a measure of success or achievement that has been achieved by a company that is measured every period of time. According There are two types of measures, namely subjective measures and objective measures. Subjective size relates to the manager's perception of the company's activities. The objective measures go hand in hand with profitability and product sales results. The achievement of the organization is the face of the organization in running its activities.

\section{Research Methodology}

The research was conducted in Makassar City and Pare-Pare City, South Sulawesi. Both locations were chosen because of the industrial center in South Sulawesi, and represented the industrial and commercial city in South Sulawesi. This research activity starts from the stage of preparation of the 
proposal until the completion of the research report is planned to be implemented for 6 (six) months, starting from April to September 2014.

The population in this study are all Small and Medium Enterprises (SMEs) in Makassar and ParePare (Data of Industry and SME Office). Both locations were chosen with the consideration that the city of Makassar and Pare-Pare as industrial centers / SMEs in South Sulawesi. Determination of sample size and withdrawal method is done by using simple random sampling method. Based on that, the number of samples is set as many as 300 respondents are divided into two sample regions that are 200 respondents in Makassar and 100 respondents in Pare-Pare City. Sampling is done on the owner of the company or can be represented in other parts (production section, marketing department) in Small and Medium Enterprises (SMEs) in South Sulawesi.

The method of analysis used to identify and test the relationship between variables in this research is path analysis. Analysis of the path (path analysis); is an analysis used to track relationships among variables in the model created. This analysis tool can explain the direct and indirect effect of a set of exogenous variables on endogenous variables.

\section{Result and Discussion}

The result of AMOS processing in testing the significance is indicated by Regression Weights: (path coefficient) is shown by the value of probability level. The probability value $=0.001$ shows the value is smaller than 0.050 (significant), thus $\mathrm{H}_{1}$ is accepted and $\mathrm{H}_{0}$ is rejected which means the coefficient of path analysis is significant. So there is a direct significant influence between environmental factors on product innovation.

The probability value $=0.007$ shows the value is smaller than 0.050 (significant), thus $\mathrm{H}_{1}$ is accepted and $\mathrm{H}_{0}$ is rejected which means the path analysis coefficient is significant. So there is a direct significant influence between environmental factors on competitive advantage.

The probability value $=0,001$ indicates value smaller than 0.050 (significant), thus $\mathrm{H}_{1}$ is accepted and $\mathrm{H}_{0}$ is rejected which means the coefficient of path analysis is significant. So there is a significant direct influence between product innovations on competitive advantage.

The probability value $=0,001$ indicates value smaller than 0.050 (significant), thus $\mathrm{H}_{1}$ is accepted and $\mathrm{H}_{0}$ is rejected which means the path analysis coefficient is significant. So, there is a direct significant influence between product innovations on SME performance.

The probability value $=0,001$ indicates value smaller than 0.050 (significant), thus $\mathrm{H}_{1}$ is accepted and $\mathrm{H}_{0}$ is rejected which means the path analysis coefficient is significant. So, there is a direct significant influence between competitiveness on the performance of SMEs. This test is shown in the following table.

Table 1. Regression Weights (Group number 1 - Default model)

\begin{tabular}{|c|c|c|c|c|c|c|}
\hline & & & Estimate & S.E. & C.R. & $P$ \\
\hline $\begin{array}{l}\text { Product } \\
\text { Innovation }\end{array}$ & $<---$ & $\begin{array}{l}\text { Environmental } \\
\text { factor }\end{array}$ & 0,57 & 0,040 & 14,006 & 0,001 \\
\hline $\begin{array}{l}\text { Competitive } \\
\text { Advantages }\end{array}$ & $<---$ & $\begin{array}{l}\text { Environmental } \\
\text { factor }\end{array}$ & 0,223 & 0,046 & 4,807 & 0,007 \\
\hline $\begin{array}{l}\text { Competitive } \\
\text { Advantages }\end{array}$ & $<---$ & $\begin{array}{l}\text { Product } \\
\text { Innovation }\end{array}$ & 0,584 & 0,052 & 11,151 & 0,001 \\
\hline $\begin{array}{l}\text { SME } \\
\text { performance }\end{array}$ & $<---$ & $\begin{array}{l}\text { Product } \\
\text { Innovation }\end{array}$ & 0,542 & 0,057 & 9,456 & 0,001 \\
\hline $\begin{array}{l}\text { SME } \\
\text { performance }\end{array}$ & $<---$ & $\begin{array}{l}\text { Competitive } \\
\text { Advantages }\end{array}$ & 0,537 & 0,055 & 9,752 & 0,001 \\
\hline
\end{tabular}

Based on the results of statistical tests show that environmental factors have a positive and significant effect on product innovation in SMEs in South Sulawesi. Characteristics of SMEs are 
strongly influenced by their environment, such as customer demand - SMEs are usually highly dependent on a few customers, so this is a factor that requires them to adopt new technologies. Pressure from suppliers - SMEs are trying to fulfill their suppliers' desire to use the latest technology.

In the field of marketing formulated steps of coaching and development, both inside and outside the country. These steps are achieved through the implementation of research and marketing studies, enhancement of management skills and marketing techniques as well as providing promotional tools and support and market testing for small businesses. It is also intended to develop marketing agencies and distribution networks, as well as to market small business products. From the management point of view, the development and development of the field of production and marketing is recognized as a strategic step in the effort to improve the performance of small business.

Optimal utilization of resources will make the business organization has advantages compared to its competitors. If the resources owned by the business organization are equal or lower than that of its competitors, then the business organization will lose its competitiveness. Conversely, if a business organization is able to maintain its superiority compared to its competitors so that existing competitors or potential competitors are not able to match or even outperform the business organization, then sustainable competitive advantage can be obtained and this will play a key role in improving business performance.

In creating the competitive advantage of a region, these factors need to be selected as basic factors and advanced factors. The first factor includes natural resources, climate, location, uneducated and semi-educated labor, and capital debt. While the second factor is more a deliberately created factor covering infrastructure networks, modern digital communication data. Highly educated human resources, as well as a trusted university research institute.

The size of the domestic market is important for the competitive advantage of a region, through an industry that has both research and development, substantial economic scale in its production, a broad technological leap, or a high degree of uncertainty in some industries, large domestic demand appeals to investment. However, domestic demand is not an advantage, except for the segments needed in other regions.

To live and grow continuously, organizations must innovate in order to reshape their competitive advantage. Organizations that lack the ability to innovate may invest time and resources in learning the market, without the ability to practice it. In the increasingly tight business world as it is today, competitive advantage becomes an important thing in the business development process going forward. A creative process that makes the product more valuable than its competitors, and in turn the business will grow in the face of such a tight competition.

\section{Conclusion}

The business environment has a positive and significant influence on product innovation in SMEs in South Sulawesi, indicating that the first hypothesis is accepted. The business environment has a positive and significant influence on competitive advantage in SMEs in South Sulawesi, indicating that the second hypothesis is accepted. Product Innovation has a positive and significant influence on competitive advantage in SMEs in South Sulawesi, indicating that the second hypothesis is accepted. Product innovation has a positive and significant influence on the performance of SMEs in South Sulawesi, indicating that the second hypothesis is accepted. Competitive advantages have a positive and significant impact on the performance of SMEs in South Sulawesi, this indicates that the second hypothesis is accepted.

\section{References}

Augusty, Ferdinand T. 2000. Marketing Management: Strategic Approach:, Research Paper Series, Semarang: Program MM Undip. 
Craicg, P.B., and M. King. 1988. Organizational Characteristics and Small Firms, Performance Revisted. Enterprise Theory and Practise, Winter.

Droge, Cornelia., and Shownee Vickrey. 1994. Source and Outcomes of Competitive Advantage: An Explanory Study in The Furniture Industry. Decision Sciences. pp.669-689.

Menon, A., Phani Tej Adidam., Sundar Bharadwaj., and S.W. Edison. 1999. Antecedents and Consequences of Marketing Strategy Making: A Model and a Test. Journal of Marketing, 63(2).

Muafi. 2008. Integration Model, Configuration, and kontijensi environment, competitive strategic, Performance. Indonesian Business, , 37, $33-41$.

Pearce, JA, and Richard Robinson. 2007. Manajemen Strategic Management; Formulation, Implementation and Controlling, Binarupa Aksara.

Slater, S.F., and John C. Narver. 1995. Market Orientation and Learning Organization. Journal of Marketing 59 (3), 63-74. 